\title{
ÉTUDE DU TRANSIT DIGESTIF DU LAPIN. EMPLOI DU POLYÉTHYLÈNE GLYCOL 4000
}

\author{
H. LE BARS, G. DEMAUX et L. GUEMON \\ Institut national agronomique, I. N.R. A., \\ 16, rue Claude-Bernard, \\ 75231 Paris Cedex 05
}

La recherche du déterminisme de la cæcotrophie et celle des mécanismes de production et d'absorption des acides organiques dans le cæcum et le colon du lapin nous ont obligé à revoir les notions de durée du transit intestinal et de mécanisme et lieu de production des fèces vraies et des cæcotrophes.

Le Polyéthylène glycol $4000(\mathrm{PEG})$, marqueur inerte est utilisé à cet effet. Il a été administré dans l'estomac ou dans le cæcum de lapins mâles Néo-zélandais de 2,5 à 4 kg grâce à deux sondes de Tygon (diamètre 2-3 $\mathrm{mm}$ ) posées à demeure. Les animaux sont nourris de granulés du commerce. Ils n'ont accès à leur mangeoire que de $\mathbf{I} 8$ heures à 8 heures le lendemain. Le PEG est dosé par la méthode turbidimétrique de Hyden. Grâce à un collecteur de fractions nous avons pu recueillir les émissions fécales d'heure en heure quand celà fut nécessaire.

\section{Résultats}

Le PEG apparaît dans les fèces dès la première heure qui suit l'administration à l'animal. L'émission de fèces dures s'interrompt pendant 3 à 5 heures, période durant laquelle le lapin recueille à l'anus les cæcotrophes. Dans notre travail cette période se place dans le nycthémère I 5 à 20 heures après le début du repas. Des cæcotrophes recueillis dès la $9^{\mathrm{e}}$ heure après l'ingestion de PEG en contiennent déjà. Ces remarques impliquent d'une part un transit rapide de l'estomac à l'anus, d'autre part, une contribution précoce de l'aliment ingéré à la formation du cæcotrophe.

Quand l'animal porte un carcan, la proportion de PEG retrouvé dans les fèces est toujours inférieure à celle identifiée dans les cæcotrophes (respectivement 35 et 53 p. Ioo du PEG ingéré, par exemple). Dans ces conditions, les quantités de PEG restant dans le tractus digestif deviennent plus vite indosables, d'où la notion de transit "écourté " quand l'animal n'ingère pas ses cæcotrophes. Chez l'animal normal, nous avons retrouvé du PEG jusqu'au ro jour après l'ingestion.

Le PEG ne semble pas cependant être le marqueur idéal pour une étude de transit chez le lapin : il est rare que l'on retrouve plus de 70 à $80 \mathrm{p}$. Ioo du marqueur ingéré et il est possible que le PEG, marqueur de la phase acqueuse, se retrouve plus aisément dans les cæcotrophes plus riches en eau d'où une interprétation erronnée des résultats.

\section{SUMMARY}

\section{STUDY OF THE DIGESTIVE TRANSIT IN THE RABBIT. USE OF POLYETHYLENE GLYCOL 4000}

Searching for the determinism of caecotrophy as well as for that of the production and absorption of organic acids in the caecum and colon in the rabbit, we were obliged to revise the notions about the intestinal transit length and the mechanism and site of production of "normal " faeces and caecotrophes. 
Polyethylene glycol 4 ooo PEG, inert marker, was used for this purpose. It was administred in the stomach or caecum of New Zealand male rabbits from 2.5 to $4 \mathrm{~kg}$ owing to two Tygon probes (diameter : $2-3 \mathrm{~mm}$ ) fixed permanently. The animals were fed commercial pellets. They were only allowed to eat from $6 \mathrm{p}$. m. to $8 \mathrm{a} . \mathrm{m}$., the next day. The PEG was dosed by the turbidimetric method of Hyden. Owing to a fraction collector, we were able to gather fecal emissions hour by hour, when it was necessary.

\title{
Results
}

The PEG appeared in the faeces from the first hour following its administration to the animal. The emission of hard faeces was interrupted for 3 to 5 hours, period during which the rabbit fetched caecotrophes at the anus. According to our results this period was situated 15 to 20 hours after the beginning of the meal. The caecotrophes collected from the 9 th hour after PEG intake already contained some of it. These observations indicated, on the one hand, that the transit was rapid from the stomach to the anus and, on the other hand, an early contribution of the food eaten to the formation of caecotrophes.

When the animal was fitted with a carcan, the proportion of PEG recovered in the faeces was always lower than that identified in the caecotrophes (for instance 35 to $53 \mathrm{p}$. roo respectively of the $P E G$ ingested). In these conditions the amounts of $P E G$ remaining in the digestive tract became rapidly indeterminable and therefore accounted for the notion of "shortened" transit, when the animal did not eat its caecotrophes. In the normal animal, we recovered PEG up to day to after its administration.

However, PEG does not seem to be an adequate marker for studying the transit in the rabbit: it is seldom that more than 70 to $80 \mathrm{p}$. Ioo of the marker ingested are recovered and it may be that PEG, marker of the aqueous phase, is more easily recovered in the caecotrophes having a higher water content. This explains the erroneous interpretation of the results.

\section{VARIATIONS DIURNES DE QUELQUES PARAMETRES BIOCHIMIQUES DANS LE CAECUM ET LE LONG DU COLON DU LAPIN}

\author{
G. DEMAUX, L. GUEMON et H. LE BARS
}

Institut national agronomique, I. N. R. A., 16, rue Claude-Bernard, 75231 Paris Cedex 05

Dans le but de préciser le lieu de formation des cæcotrophes dans le colon et de voir si, dans le temps, il était possible d'infirmer à partir du matériel présent dans le colon, la nature de l'émission fécale, nous avons étudié les variations des paramètres biochimiques suivants : $\mathrm{pH}$, matière sèche, taux de l'Azote total $(\mathrm{N})$, taux des acides gras volatils totaux (AGV). Une étude complémentaire nous aménera à préciser la nature des acides et leur variation respective.

Des lapins mâles Néo-Zélandais pesant de 2,5 à $4 \mathrm{~kg}$, nourris ad libitum de granulés du commerce, sont sacrifiés par choc cervical à $8 \mathrm{~h}$ le matin, entre $\mathrm{I}_{3}$ et $\mathrm{I} 5 \mathrm{~h}$ et entre I $8 \mathrm{~h} 30$ et I9 h 30 le soir.

Annales de Biologie animale. - I973. 